\title{
PETROGENETIC SIGNIFICANCE OF SPINELS FROM SERPENTINISED PERIDOTITES FROM THE VERIA- NAOUSA OPHIOLITE
}

\author{
Rogkala A. ${ }^{1}$, Petrounias P. ${ }^{1}$, Tsikouras B. ${ }^{1,2}$ and Hatzipanagiotou K. ${ }^{1}$ \\ ${ }^{1}$ University of Patras, Department of Geology, Section of Earth Materials, 265 00, Patras, Greece \\ ${ }^{2}$ Universiti Brunei Darussalam, Faculty of Science, Physical and Geological Sciences, Jalan \\ Tungku Link, Gadong BE1410, Bandar Seri Begawan, Brunei Darussalam
}

\begin{abstract}
The Veria-Naousa ophiolitic complex represents a dismembered ophiolite unit, which is superimposed on a basement consisting of rocks belonging to the Pelagonian and Axios (Almopias subzone) isopic zones in northern Greece. Mantle peridotites are composed of variably serpentinised lherzolite and harzburgite intruded by a sparse network of pyroxenitic dykes. The serpentinised lherzolite and harzburgite contain Alspinels $(\mathrm{Cr} \#=38.83-42.52$ and $M g \#=58.94-64.77), C r$-spinels $(C r \#=43.37-64.92$ and $M g \#=49.20-58.66)$ and magnesiochromites $(C r \#=53.93-57.13$ and $M g \#=55.73-$ 61.71). All of them display commonly richer-in-Cr cores rimmed by secondary ferrian chromite and magnetite. Whole-rock geochemicall compositions and primary spinel chemical composition of these peridotites are analogous to peridotites that formed in a suprasubduction zone. It is supported that the Mantle peridotites of the VeriaNaousa ophiolitic complex formed in a back-arc basin.

Keywords: Almopias subzone, backarc basin, Mantle impregnation.

\section{Пєрí $\eta \psi \eta$}

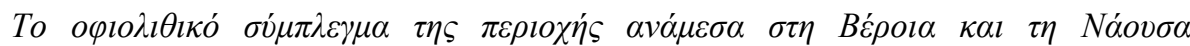

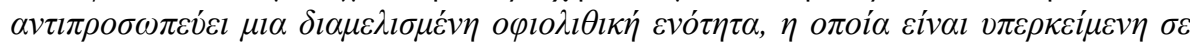

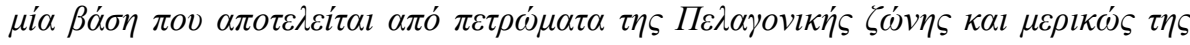

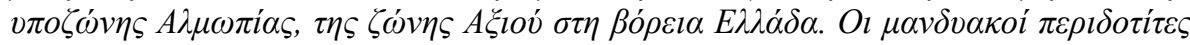

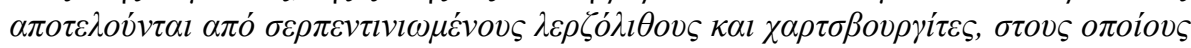

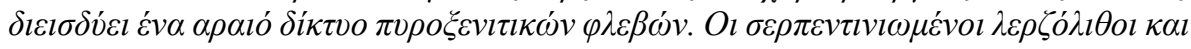

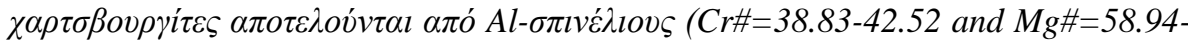

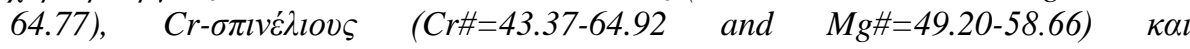

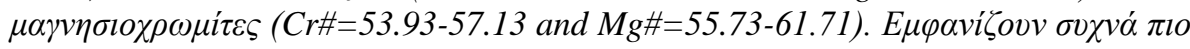

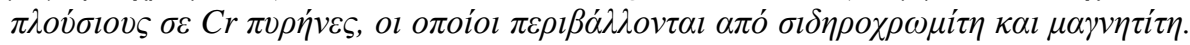
Ol

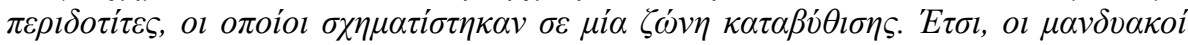

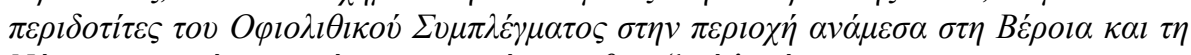

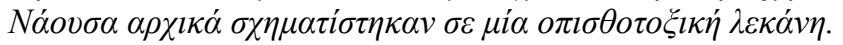

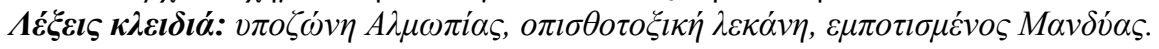




\section{Introduction}

Spinels are commonly used as "petrogenetic indicators", occurring in ultramafic rocks of ophiolite complexes. They display a wide range of compositions reflecting their primary magmatic or secondary origin (Barnes and Roeder, 2001; Ghosh et al., 2013). Primary spinel can be well maintained during serpentinisation, hence unaltered spinels in serpentinite can be used as a petrogenetic and geotectonic indicator because their chemical composition depends on the petrogenesis and physical conditions of the host peridotites (Zhou et al., 1994; Karipi et al., 2007; Oh et al., 2010). The prime purpose of this paper is to present new data on the chemical variability of spinel-group minerals occurring in serpentinised peridotites from the Veria-Naousa ophiolite, north Greece, aiming also to unravel the petrogenetic processes during their formation.

\section{Geological setting}

Extensive fieldwork in the Veria-Naousa ophiolitic complex focused mainly on the distribution and mode of development of the ophiolitic rocks, as well as their relation to the adjacent formations. These rocks extend throughout the area between Veria and Naousa towns and belong geotectonically to the Almopias subzone of the Axios isopic zone, in northern Greece (Fig. 1).

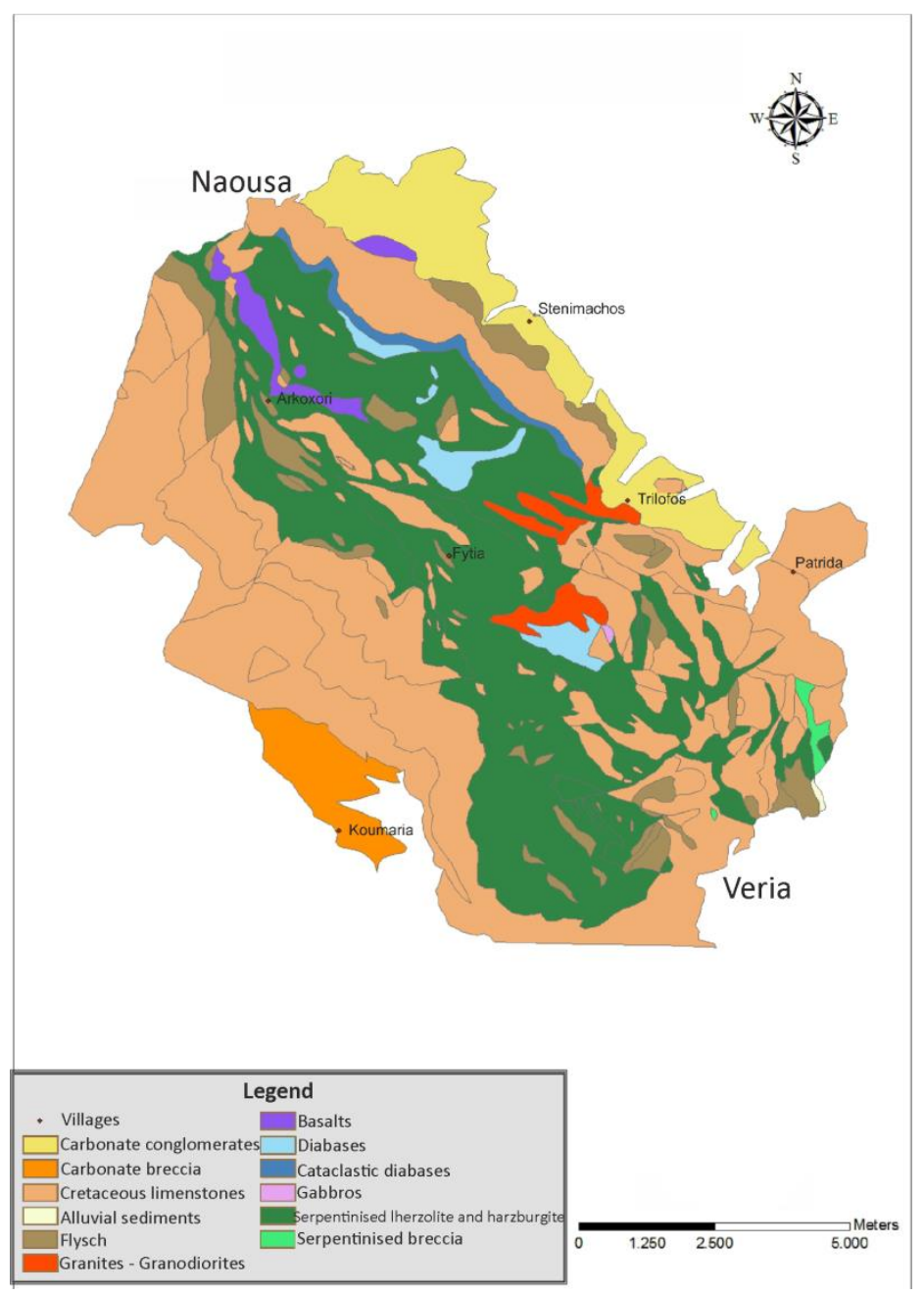

Figure 1 - Geological map of the Veria-Naousa region. 
They represent remnants of oceanic lithosphere which were thrust from one or more ocean basins. They have been obducted onto the Cretaceous platform carbonates and a flysch succession of the Pelagonian Zone during Upper Jurassic to Lower Cretaceous time (Mercier et al., 1975; Economou, 1983; Michailidis, 1990; Economou-Eliopoulos, 2003; Tsoupas and Economou-Eliopoulos, 2008). The ophiolite suite includes, from base to top, serpentinised lherzolite and harzburgite, intruded by a sparse network of pyroxenitic dykes, as well as gabbros, diabases and pillow basalts. It is dismembered and scattered due to intensive tectonism of the area. The serpentinised peridotites are intensely tectonised, showing a dense network of joints. Rare rodingite dykes occur in the serpentinised ultramafic rocks. The ophiolite is unconformably overlain by sediments (conglomeratic limestone, flysch). Also, a granitic intrusion in the serpentinised mass is observed near the village of Trilofos.

\section{Analytical methods}

The mineralogical and textural characteristics of the samples were studied in polished-thin sections in optical and scanning electron microscopes (SEM). Spinel microanalyses were performed using a JEOL JSM-6300 SEM equipped with EDS and WDS and THETA software at the Laboratory of Electron Microscopy and Microanalysis, University of Patras. Operating conditions were accelerating voltage $15 \mathrm{kV}$ and beam current $3.3 \mathrm{nA}$, with $4 \mu \mathrm{m}$ diameter beam. Whole-rock chemical analyses for major and trace elements were performed at ACME Analytical Laboratories LTD in Canada. Whole-rock major element analyses were carried out using a XRF spectrometer and a sequential spectrometer (ICP-ES). Trace elements were determined on totally digested samples by inductively coupled plasma-mass spectrometry (ICP-MS). Detection limits for major elements is $0.01 \mathrm{wt} . \%$ and for trace elements is 1 and $0.1 \mathrm{ppm}$. The analytical precision calculated from replicate analyses is better than $3 \%$ for most major elements and better than $5 \%$ for trace elements.

\section{Results}

\subsection{Petrographic features}

\subsubsection{Serpentinised Lherzolite}

The lherzolite samples are intensively serpentinised, therefore their classification was made based on their normative mineralogical composition and whole-rock geochemical analyses. Serpentine is the dominant alteration product forming mesh, hourglass, ribbon and bastite textures; lesser amounts of chlorite and magnetite occur, too. Their primary modal mineralogical assemblage has been mostly obliterated by alteration and only few relics of olivine, orthopyroxene, clinopyroxene and spinel are present. They have two types of spinels, Al-spinel and $\mathrm{Cr}$-spinel, both forming subhedral to euhedral grains with lobate boundaries (Fig. 2a, b, c), and are usually frequently veined and surrounded by thin rims of ferrian chromite and magnetite, due to alteration (Fig. 2c). A scarce network of calcite veins occurs, too.

\subsubsection{Serpentinised Harzburgite}

The primary assemblage of the harzburgite constitutes less than $20 \%$ of the mode and comprises relics of orthopyroxene, rare clinopyroxene, olivine, as well as magnesiochromite and Cr-spinel (Fig. $2 \mathrm{~d}$ ). Serpentine is the main alteration product showing mesh, ribbon and intersertal textures. Chlorite and magnetite are also products of hydrothermal alteration of the harzburgite. Orthopyroxene appears as subhedral porphyroclasts and most of them show exsolution lamellae of clinopyroxene, typical feature of mantle peridotites. The magnesiochromite and $\mathrm{Cr}$-spinel crystals are subhedral to euhedral and scanning electron microscopic observation revealed that infrequently they show an irregular distribution of ferrian chromite compositional areas, at their rims (Fig. 2e, f). The boundary between the magnesiochromite and $\mathrm{Cr}$-spinel (either unaltered or altered) and the ferrian chromite is curved and lobate. 

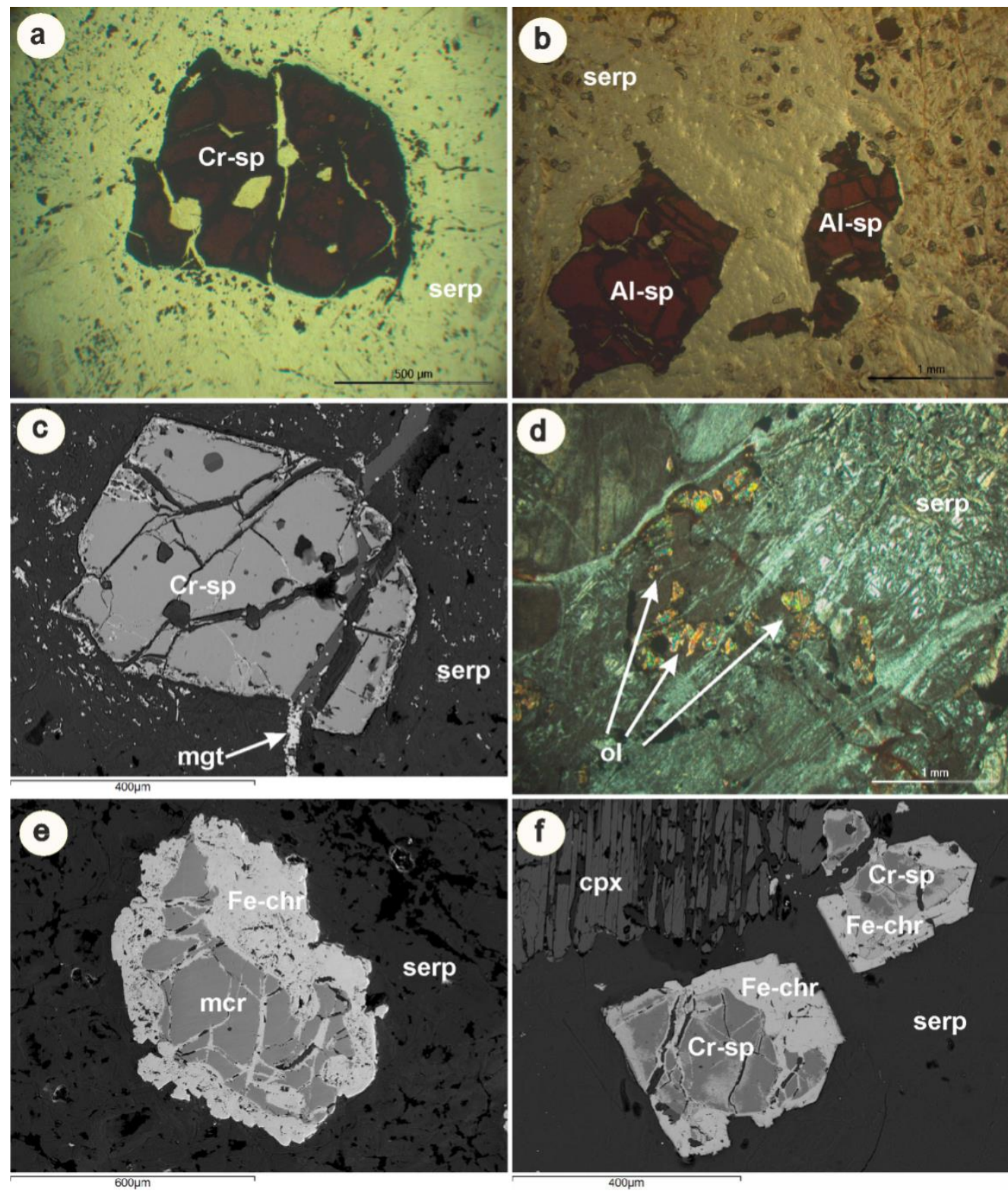

Figure 2 - Textural characteristics of the serpentinised peridotites from Veria-Naousa: a. Photomicrograph of a Cr-spinel (Cr-sp) in serpentinised mass (lherzolite sample BE.8B, PPL), b. Photomicrograph of Al-spinel (Al-sp) crystals (serpentinised lherzolite BE.58, PPL), c. Backscattered electron image of a $\mathrm{Cr}$-spinel crystal with irregular distribution of poorerin-Cr compositional areas, at its rim (sample BE.8B) d. Photomicrograph of relics of olivine (ol) surrounded by ribbon and intersertal serpentine (serp) in serpentinised harzburgite (sample BE.12), e. Backscattered electron image of a severely altered magnesiochromite (mcr) crystal surrounded by thick ferrian chromite (Fe-chr) in serpentinised harzburgite (sample BE.14), f. Backscattered electron image of $\mathrm{Cr}$ - Spinel (Cr-Sp) crystals surrounded by ferrian chromite and altered clinopyroxene (cpx) to chlorite in serpentinised harzburgite (sample BE.12). 


\subsection{Chemical composition of spinel-group minerals}

Representative compositions of spinel-group minerals from the Veria-Naousa serpentinised peridotites are given in Tables 1 and 2. Cationic ratios were calculated on the basis of 8 oxygen atoms assuming spinel stoichiometry.

Table 1 - Representative electron microanalyses of spinel-group minerals from serpentinised lherzolites of Veria-Naousa.

\begin{tabular}{|c|c|c|c|c|c|c|c|}
\hline \multirow[b]{2}{*}{ Sample } & \multicolumn{5}{|c|}{ Spinel } & \multicolumn{2}{|c|}{ Ferrian chromites } \\
\hline & BE.8B & BE. $8 \mathrm{~B}$ & BE. 58 & BE. 58 & BE. 58 & BE.8B & BE. $8 \mathrm{~B}$ \\
\hline $\begin{array}{l}\text { Oxide } \\
\text { wt. \% }\end{array}$ & 1 & 2 & 1 & 2 & 3 & 1 & 2 \\
\hline $\mathrm{SiO}_{2}$ & - & - & - & - & - & - & - \\
\hline $\mathrm{TiO}_{2}$ & 0.11 & 0.16 & - & - & - & - & - \\
\hline $\mathrm{Al}_{2} \mathrm{O}_{3}$ & 18.34 & 17.56 & 32.44 & 35.85 & 34.44 & - & - \\
\hline $\mathrm{Cr}_{2} \mathrm{O}_{3}$ & 47.09 & 48.45 & 35.49 & 33.93 & 34.98 & 43.89 & 42.23 \\
\hline $\mathrm{FeO}^{\mathrm{t}}$ & 21.56 & 22.76 & 17.27 & 18.16 & 15.90 & 43.67 & 46.01 \\
\hline $\mathrm{MnO}$ & - & - & - & - & - & 9.01 & 8.57 \\
\hline $\mathrm{MgO}$ & 11.76 & 10.45 & 14.39 & 13.82 & 15.06 & 0.81 & 0.66 \\
\hline $\mathrm{CaO}$ & - & 0.04 & - & - & - & 0.12 & - \\
\hline $\mathrm{ZnO}$ & 0.28 & 0.22 & - & - & - & 2.21 & 1.86 \\
\hline Total & 99.14 & 99.64 & 99.59 & 101.76 & 100.38 & 99.71 & 99.33 \\
\hline \multicolumn{8}{|c|}{ Structural formula on the basis of $8 O$} \\
\hline $\mathrm{Si}$ & - & - & - & - & - & - & - \\
\hline $\mathrm{Al}$ & 0.686 & 0.662 & 1.122 & 1.209 & 1.171 & - & - \\
\hline $\mathrm{Cr}$ & 1.182 & 1.225 & 0.824 & 0.767 & 0.798 & 1.298 & 1.250 \\
\hline $\mathrm{Fe}^{3+}$ & 0.113 & 0.094 & 0.054 & 0.024 & 0.031 & 0.580 & 0.647 \\
\hline $\mathrm{Ti}$ & 0.003 & 0.004 & - & - & - & - & - \\
\hline $\mathrm{Mg}$ & 0.557 & 0.498 & 0.630 & 0.589 & 0.648 & 0.045 & 0.037 \\
\hline $\mathrm{Fe}^{2+}$ & 0.456 & 0.515 & 0.370 & 0.411 & 0.352 & 0.787 & 0.794 \\
\hline $\mathrm{Mn}$ & - & - & - & - & - & 0.286 & 0.272 \\
\hline $\mathrm{Zn}$ & 0.007 & 0.005 & - & - & - & 0.061 & 0.051 \\
\hline $\mathrm{Ca}$ & - & 0.001 & - & - & - & 0.005 & - \\
\hline Total & 3.007 & 3.005 & 3.000 & 3.000 & 3.000 & 3.061 & 3.007 \\
\hline $\mathrm{Cr} \#$ & 63.27 & 64.92 & 42.33 & 38.83 & 40.52 & 100.00 & 100.00 \\
\hline Mg\# & 54.80 & 49.20 & 62.98 & 58.94 & 64.77 & 5.43 & 4.43 \\
\hline
\end{tabular}


Table 2 - Representative electron microanalyses of spinel-group minerals from serpentinised harzburgites of Veria-Naousa.

\begin{tabular}{|c|c|c|c|c|c|c|c|}
\hline \multirow{2}{*}{ Sample } & \multicolumn{5}{|c|}{ Spinel } & \multicolumn{2}{|c|}{ Ferrian chromites } \\
\hline & BE.12 & BE.14 & BE.14 & BE.14 & BE.14 & BE. 12 & BE.14 \\
\hline $\begin{array}{l}\text { Oxide } \\
\text { wt. \% }\end{array}$ & 1 & 1 & 2 & 3 & 4 & 1 & 1 \\
\hline $\mathrm{SiO}_{2}$ & 0.75 & - & - & - & - & 2.24 & - \\
\hline $\mathrm{TiO}_{2}$ & 0.09 & 0.19 & 0.20 & 0.28 & 0.01 & 0.03 & 0.53 \\
\hline $\mathrm{Al}_{2} \mathrm{O}_{3}$ & 31.34 & 24.01 & 22.67 & 24.29 & 24.89 & 3.40 & - \\
\hline $\mathrm{Cr}_{2} \mathrm{O}_{3}$ & 35.78 & 47.51 & 45.03 & 46.6 & 43.43 & 25.78 & 40.42 \\
\hline $\mathrm{FeO}^{\mathrm{t}}$ & 17.36 & 17.32 & 17.29 & 17.90 & 17.03 & 58.26 & 51.56 \\
\hline $\mathrm{MnO}$ & - & - & - & 0.05 & - & 5.03 & 5.36 \\
\hline $\mathrm{MgO}$ & 13.68 & 12.23 & 13.63 & 12.71 & 13.78 & 3.16 & - \\
\hline $\mathrm{NiO}$ & - & - & - & & - & 0.10 & - \\
\hline $\mathrm{ZnO}$ & 0.20 & 0.37 & 0.30 & 0.11 & 0.31 & 1.08 & 1.64 \\
\hline Total & 99.20 & 101.63 & 99.12 & 101.94 & 99.45 & 99.08 & 99.51 \\
\hline \multicolumn{8}{|c|}{ Structural formula on the basis of $8 O$} \\
\hline $\mathrm{Si}$ & 0.022 & - & - & - & - & 0.080 & - \\
\hline $\mathrm{Al}$ & 1.080 & 0.860 & 0.824 & 0.862 & 0.894 & 0.142 & - \\
\hline $\mathrm{Cr}$ & 0.841 & 1.142 & 1.098 & 1.109 & 1.046 & 0.724 & 1.198 \\
\hline $\mathrm{Fe}^{3+}$ & 0.004 & - & 0.055 & 0.011 & 0.046 & 0.916 & 0.681 \\
\hline $\mathrm{Ti}$ & 0.002 & 0.004 & 0.005 & 0.006 & - & 0.001 & 0.015 \\
\hline $\mathrm{Mg}$ & 0.606 & 0.554 & 0.627 & 0.570 & 0.626 & 0.167 & - \\
\hline $\mathrm{Ni}$ & - & - & - & - & - & 0.003 & - \\
\hline $\mathrm{Fe}^{2+}$ & 0.427 & 0.440 & 0.391 & 0.439 & 0.388 & 0.815 & 0.936 \\
\hline $\mathrm{Mn}$ & - & - & - & 0.001 & - & 0.151 & 0.170 \\
\hline $\mathrm{Zn}$ & 0.004 & 0.008 & 0.007 & 0.002 & 0.007 & 0.028 & 0.045 \\
\hline Total & 3.004 & 3.008 & 3.007 & 3.002 & 3.007 & 3.028 & 3.045 \\
\hline $\mathrm{Cr} \#$ & 43.37 & 57.03 & 57.13 & 56.27 & 53.93 & 83.18 & 100.00 \\
\hline $\mathrm{Mg} \#$ & 58.66 & 55.73 & 61.55 & 56.49 & 61.71 & 17.39 & 0.00 \\
\hline
\end{tabular}

Chemical classification in spinel-group minerals of the serpentinised peridotites from Veria-Naousa region is illustrated in a $\mathrm{Mg} /\left(\mathrm{Mg}+\mathrm{Fe}^{2+}\right)$ vs. $\mathrm{Cr} /(\mathrm{Cr}+\mathrm{Al})$ diagram (Fig. 3a). The lherzolitic Al-spinel and harzburgitic Cr-spinel plot in the field of "spinel", while the lherzolitic Cr-spinel and magnesiochromite plot in the field of "magnesiochromite" (Fig. 3a).

The serpentinised lherolite contains Cr-poor and Mg-rich, Al-spinels, with $\mathrm{Cr} \#[=100 \times \mathrm{Cr} /(\mathrm{Cr}+\mathrm{Al})]$ in the range from 38.83 to 40.52 (Table 1) and $\mathrm{Mg} \#\left[=100 \times \mathrm{Mg} /\left(\mathrm{Mg}+\mathrm{Fe}^{2+}\right)\right]$ ranging from 58.94 to 64.77. The chemical composition of the analysed Al-spinels is characterised by poorer $\mathrm{FeO}^{\mathrm{t}}(15.9$ 0-18.16 wt. \%) than the Cr-spinels. Furthermore, the lherzolitic Cr-spinels contain appreciable amo unts of $\mathrm{ZnO}\left(0.22-0.28\right.$ wt. \%) and $\mathrm{TiO}_{2}(0.11-0.16$ wt. \%).

The serpentinised harzburgites display magnesiochromites and rare $\mathrm{Cr}$-spinels. Magnesiochromite is distinguished from $\mathrm{Cr}$-spinel in containing a considerable amount of $\mathrm{Fe}^{2+}$ replacing $\mathrm{Mg}$, and displaying $\mathrm{Fe}^{2+}>\mathrm{Mg}$ (Deer et al., 1992). The Cr-spinels are richer in $\mathrm{Al}_{2} \mathrm{O}_{3}, \mathrm{MgO}$ and poorer in $\mathrm{Cr}_{2} \mathrm{O}_{3}, \mathrm{TiO}_{2}, \mathrm{ZnO}, \mathrm{FeO}$ than the magnesiochromites.Cr\# in the harzburgitic magnesiochromites and Cr-spinels ranges from 54.55 to 57.78 whereas Mg\# ranges from 55.73 to 61.07 (see table 2 and Fig. 
3). They contain noticeable amounts of $\mathrm{TiO}_{2}$ (generally 0.10 to $0.28 \mathrm{wt}$. \%, with few exceptions that contain lesser $\mathrm{TiO}_{2}$ ) and $\mathrm{ZnO}(0.11$ to 0.37 wt. \%), too.

Secondary spinels were formed during serpentinisation along fractures in the primary spinel crystals, in both rocks. Two groups of secondary spinels are observed: the first group includes magnetite and $\mathrm{Cr}$-magnetite, which are rich in $\mathrm{FeO}^{\mathrm{t}}$, whereas the second group includes ferrian chromite enriched in $\mathrm{Cr}_{2} \mathrm{O}_{3}, \mathrm{TiO}_{2}$ and $\mathrm{MnO}$ and poorer in $\mathrm{FeO}^{\mathrm{t}}$ compared to the magnetite.

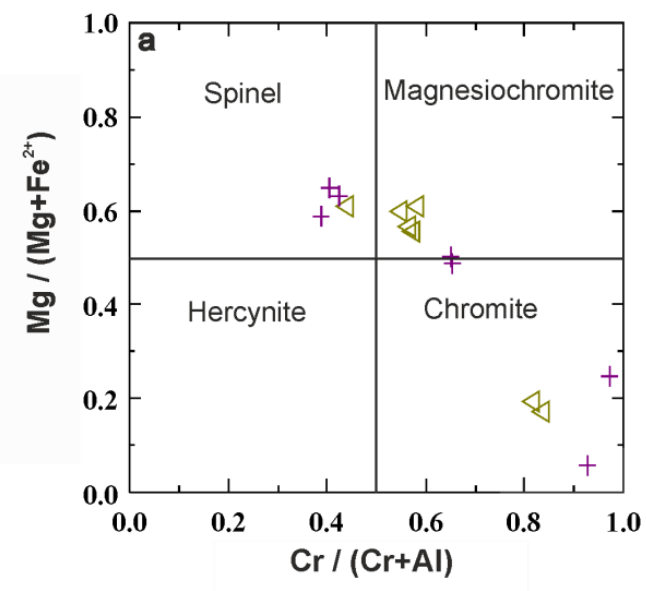

+ Lherzolite

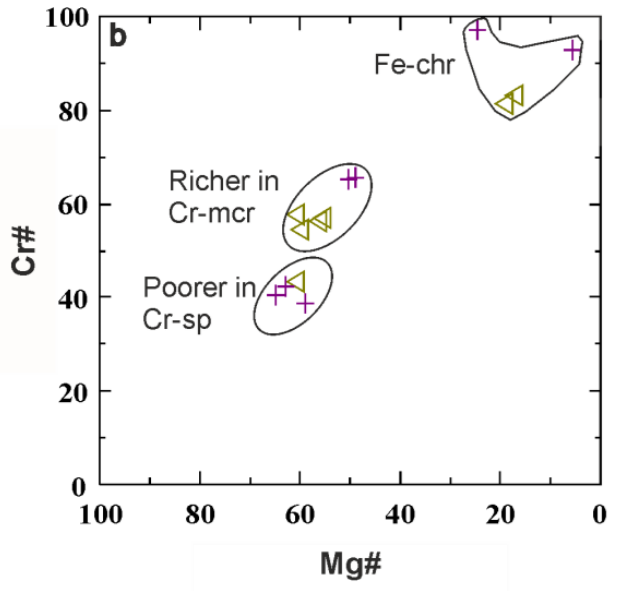

$\triangleleft$ Harzburgite

Figure 3 - a. Chemical classification diagram for the spinel-group minerals of the VeriaNaousa serpentinised peridotites, b. Spinel compositions from Veria-Naousa serpentinised peridotites, in terms of $\mathrm{Cr} \#$ against $\mathrm{Mg \#}$.

Table 3 - Representative geochemical analyses of serpentinised peridotites from VeriaNaousa ophiolite. - Below detection limit.

\begin{tabular}{|c|c|c|c|c|c|}
\hline & $\begin{array}{c}\text { Lherzolite } \\
\text { BE.58 }\end{array}$ & $\begin{array}{c}\text { Harzburgite } \\
\text { BE.14 }\end{array}$ & & $\begin{array}{c}\text { Lherzolite } \\
\text { BE.58 }\end{array}$ & $\begin{array}{c}\text { Harzburgite } \\
\text { BE.14 }\end{array}$ \\
\hline \multicolumn{3}{|c|}{ Major elements (wt. \%) } & \multicolumn{3}{|c|}{ Trace elements (ppm) } \\
\hline $\mathrm{SiO}_{2}$ & 41.45 & 40.83 & $\mathrm{Zn}$ & 25 & 24 \\
\hline $\mathrm{TiO}_{2}$ & 0.09 & - & $\mathrm{Rb}$ & 1.3 & 0.3 \\
\hline $\mathrm{Al}_{2} \mathrm{O}_{3}$ & 1.33 & 0.46 & $\mathrm{Sr}$ & 57.0 & 0.8 \\
\hline $\mathrm{Fe}_{2} \mathrm{O}_{3}{ }^{\mathrm{t}}$ & 7.42 & 9.18 & $\mathrm{Y}$ & 1.8 & 0.2 \\
\hline $\mathrm{MnO}$ & 0.11 & 0.12 & $\mathrm{Zr}$ & 8.4 & 0.2 \\
\hline $\mathrm{MgO}$ & 29.56 & 35.11 & $\mathrm{Nb}$ & 1.0 & - \\
\hline $\mathrm{CaO}$ & 3.29 & 0.06 & $\mathrm{~Pb}$ & 0.6 & 2.7 \\
\hline $\mathrm{Na}_{2} \mathrm{O}$ & 0.01 & - & $\mathrm{Ba}$ & 8 & 1 \\
\hline $\mathrm{K}_{2} \mathrm{O}$ & - & - & $\mathrm{V}$ & 42 & 16 \\
\hline $\mathrm{P}_{2} \mathrm{O}_{5}$ & 0.01 & - & $\mathrm{Sc}$ & 8 & 6 \\
\hline LOI & 15.6 & 13.1 & $\mathrm{Ga}$ & 2.1 & 2.9 \\
\hline Total & 98.87 & 98.86 & Hf & 0.2 & - \\
\hline \multicolumn{3}{|c|}{ Trace elements (ppm) } & $\mathrm{Ta}$ & - & - \\
\hline $\mathrm{Cr}$ & 2374 & 1669 & Th & 0.2 & - \\
\hline $\mathrm{Co}$ & 82.5 & 114.3 & $\mathrm{U}$ & 0.3 & - \\
\hline $\mathrm{Ni}$ & 1944.6 & 2743.7 & $\mathrm{MgO} / \mathrm{FeO}^{\mathrm{t}}$ & 4.43 & 4.25 \\
\hline $\mathrm{Cu}$ & 5.1 & 8.3 & & & \\
\hline
\end{tabular}




\subsection{Whole-rock geochemical features}

Whole-rock compositions of representative serpentinised peridotite samples from the Veria-Naousa ophiolite are given in Table 3. The high degree of serpentinisation is reflected by high loss-onignition (LOI) values. Both samples are $\mathrm{Mg}$-rich, $\mathrm{Al}$-poor and alkali poor rocks. The serpentinised harzburgite is characterised by depletion in $\mathrm{TiO}_{2}$ and $\mathrm{Na}_{2} \mathrm{O}$ and low amounts of $\mathrm{Al}_{2} \mathrm{O}_{3}$ and $\mathrm{CaO}$. These values correspond to highly depleted upper mantle peridotites (McDonough and Sun, 1995; $\mathrm{Niu}, 1997)$. The lherzolite is richer in the incompatible elements $\mathrm{Rb}, \mathrm{Sr}, \mathrm{Y}$ and $\mathrm{Zr}$ relative to the harzburgite, further evidence for the relatively fertile character of the first compared to the last rock (Table 3). However, this enrichment is not as high as in chondritic lherzolites, fact that along with the enrichment in the compatible $\mathrm{Cr}$ indicate that the lherzolite has also undergone a stage of depletion.

\section{Discussion}

Spinel-group minerals from the serpentinised rocks of Veria-Naousa ophiolite reveal a multi-stage genesis in the different types of their host peridotites. Textural and chemical features of the studied spinel-group minerals indicate that an early partial melting process and a subsequent episode of melt-rock interaction in the mantle section played a decisive role in their genesis. The partially depleted character of the lherzolite is also compatible with an early stage of melting and depletion. This less depleted lherzolite has spinels poorer in Cr\# (Al-spinels and $\mathrm{Cr}$-spinels), compared with the highly depleted harzburgite, that contains $\mathrm{Cr}$-spinel and magnesiochromite with increased $\mathrm{Cr}$.

Unlike the Al-spinels, which are depleted in $\mathrm{TiO}_{2}$ and $\mathrm{ZnO}, \mathrm{Cr}$-spinels (including magnesiochromites) have rather high amounts of these oxides, which reflects the involvement of impregnating melts during the evolution of both peridotites (Farahat et al., 2011). The development of subhedral to euhedral Cr-spinel grains in the serpentinised harzburgite, as well as lack of significant correlation between $\mathrm{Cr} \#$ and $\mathrm{Mg \#}$ in the magnesiochromite and $\mathrm{Cr}$-spinel are also consistent with a melt-peridotite interaction episode and their crystallisation from magmatic processes (Zhou et al., 1994, 2005).

The Cr-spinels and magnesiochromite in the lherzolite and harzburgite display $\mathrm{Cr} \#<60$, which is typical of oceanic ophiolites (including backarc basins; Dick and Bullen, 1984). The composition and textural characteristics of the Al-spinels suggest that they can be considered as a residual phase after a first stage melting episode of a fertile peridotite, during adiabatic decompression under a midocean spreading center. The textural features and composition of $\mathrm{Cr}$-spinels (including magnesiochromites combined with the highly depleted nature of the harzburgite are consistent with evolution in a back-arc basin. The analysed spinel-group minerals from the Veria-Naousa serpentinised peridotites display similar chemical characteristics from the Othrys and Vourinos ophiolite complexes of analogous SSZ origin (Karipi et al., 2006; Kapsiotis, 2013).

Furthermore, the formation of ferrian-chromite and chromian magnetite alteration rims around the Al-spinels, Cr-spinels and magnesiochromites is assigned to secondary processes that typically occur during serpentinisation (Khedr and Arai, 2011; Singh et al., 2013; Banerjee et al., 2015; Maulana et al., 2015). Notable Mn-erichments in the ferrian chromite zones involve interaction of hydrothermal fluids that were likely rich in Mn, similarly to other ophiolite complexes (e.g., Gahlan and Arai, 2007).

\section{Conclusions}

Three different types of primary spinel compositions have been distinguished within the Veria-Naousa serpentinised peridotites: Al-spinel, Cr-spinel and magnesiochromite, occurring as subhedral to euhedral crystals, surrounded by secondary ferrian chromite and magnetite rims. The serpentinised peridotites of the Veria-Naousa ophiolite represent a mantle part of an SSZ ophiolite complex and their evolution involves an early depletion stage followed by melt impregnation in a back-arc basin tectonic 
setting. During the incipient stages of spreading variable degrees of melting depleted the lherzolite and harzburgite at different degrees. Subsequent evolution of the basin, along with the involvement of subduction-related hydrous fluids are thought to be responsible for the production of melts that triggered the formation of $\mathrm{Cr}$-spinels and magnesiochromites and refertilised the harzburgite. After the igneous stage, the peridotites underwent a hydrothermal alteration event that caused alteration of the primary spinel-group minerals to ferrian chromite and magnetite.

\section{References}

Banerjee, R., Ray, D. and Ishii, T., 2015. Mineral Chemistry and Alteration Characteristics of Spinel in Serpentinised Peridotites from the Northern Central Indian Ridge, Jour. Geol. Soc. India, 86, 41-51.

Barnes, S.J. and Roeder, P.L., 2001. The Range of Spinel Compositions in Terrestrial Mafic and Ultramafic Rocks, J. Petrol., 42, 2279-2302.

Deer, W.A., Howie, R.A. and Zussman, S., 1992. The rock-forming minerals, Library of Congress Cataloguing in Publication Data, 558-568.

Dick, H.J.B. and Bullen, T., 1984. Cr-spinel as a petrogenetic indicator in abyssal and alpine-type peridotites and spatially associated lavas, Contrib, Mineral. Petrol., 86, 54-76.

Economou, M., 1983. A short note on the evolution of the Vermion ophiolite complex (MacedoniaGreece), Ofioliti, 8, 333-338.

Economou-Eliopoulos, M., 2003. Apatite and Mn, Zn, Co-enriched chromite in Ni-laterites of northern Greece and their genetic significance, Journal of Geochemical Exploration, 80, 41-54.

Farahat, E.S., Hoinkes, G. and Mogessie, A., 2011. Petrogenetic and geotectonic significance of Neoproterozoic suprasubduction mantle as revealed by the Wizer ophiolite complex, Central Eastern Desert, Egypt, Int. J. Earth Sci., 100, 1433-1450.

Gahlan, H.A. and Arai, S., 2007. Genesis of peculiarly zoned Co, Zn and Mn-rich chromian spinel in serpentinite of Bou-Azzer ophiolite, Anti-Atlas, Morocco, Jour. Min. Petrol. Sci., 102, 69-85.

Ghosh, B., Morishita, T. and Bhatta, K., 2013. Significance of chromian spinels from the mantle sequence of the Andaman Ophiolite, India: Paleogeodynamic implications, Lithos, 164-167, 86-96.

Kapsiotis, A., 2013. Origin of mantle peridotites from the Vourinos Ophiolite Complex, Greece, as deduced from Cr-spinel morphological and chemical variations, Journal of Geosciences, 58, 217-231.

Karipi, S., Tsikouras, B. and Hatzipanagiotou, K., 2006. The petrogenesis and tectonic setting of ultramafic rocks from Iti and Kallidromon Mountains, continental Central Greece: vestiges of the Pindos ocean, Can. Mineral., 44, 267-287.

Karipi, S., Tsikouras, B., Hatzipanagiotou, K. and Grammatikopoulos, T.A., 2007. Petrogenetic significance of spinel-group minerals from the ultramafic rocks of the Iti and Kallidromo ophiolites (Central Greece), Lithos, 99, 136-149.

Khedr, M.Z. and Arai, S., 2011. Petrology and geochemistry of chromian spinel-bearing serpentinites in the Hide Marginal Belt (Ise area, Japan): characteristics of their protoliths, $J$. Miner. Petrol. Sci., 106, 225-260.

Maulana, A., Christy, A.C. and Ellis, D., 2015. Petrology, geochemistry and tectonic significance of serpentinised ultramafic rocks from the South Arm of Sulawesi, Indonesia, Chem. Erde, 75, 73-87.

Mcdonough, W.F. and Sun, S.S., 1995. The composition of the Earth. Chem. Geol., 120, 223-253.

Mercier, J., Vergely, P. and Bebien, J., 1975. Les ophiolites helleniques "obductees" au Jurassique superieur sont-elles les vestiges d'un ocean tethysien ou d'une mer marginale perieuropeenne, C.R. Somm. Soc. Geol. France, 17, 108-112.

Michailidis, K.M., 1990. Zoned chromites with high Mn-contents in the Fe-Ni-Cr-laterite ore deposits from the Edessa area in Northern Greece, Mineral. Deposita, 25, 190-197.

Niu, Y., 1997. Mantle melting and melt extraction processes beneath ocean ridges: evidence from abyssal peridotites, J. Petrol., 38, 1047-1074.

Oh, C.W., Rajesh, V.J., Seo, J., Choi, S.G. and Lee, J.H., 2010. Spinel compositions and tectonic relevance of the Bibong ultramafic bodies in the Hongseong collision belt, South Korea, Lithos, 117, 198-208. 
Singh, N.I., Devi, L.D. and Chanu, Th.Y., 2013. Petrological and Geochemical Study of Serpentinised Peridotites from the Southern Part of Manipur Ophiolitic Complex, Northeast India, Jour. Geol. Soc. India, 82, 121-132.

Tamura, A. and Arai, S., 2005. Unmixed spinel in chromitite from the Iwanai-dake peridotite complex. Hokkaido, Japan: a reaction between peridotite and highly oxidized magma in the mantle wedge, Am. Mineral., 90, 473-480.

Tsouras, G. and Economou-Eliopoulos, M., 2008. High PGE contents and extremely abundant PGEminerals hosted in chromitites from the Veria ophiolite complex, Northern Greece, Ore Geol. Rev., 33, 3-19.

Zhou, M.F., Robinson, P.T. and Bai, W.J., 1994. Formation of podiform chromitites by melt/rock iteraction in the upper mantle, Mineralium Deposita, 29, 98-101. 